\title{
PENGARUH MOTIVASI DAN MINAT BELAJAR TERHADAP HASIL BELAJAR MATEMATIKA PESERTA DIDIK KELAS VII DI MTS AL- MUTTAQIN BUPER JAYAPURA
}

\author{
Binti Khotimah $^{1}$ \\ IAIN Fattahul Muluk Papua, 99351 \\ bintikhotimah123@gmail.com \\ Dewi Nofrita ${ }^{2}$ \\ IAIN Fattahul Muluk Papua, 99351 \\ dnsjafri@gmail.com \\ Nining Puji Lestari ${ }^{3}$ \\ IAIN Fattahul Muluk Papua, 99351 \\ lestaning112988@gmail.com
}

\begin{abstract}
Abstrak
Ada beberapa faktor yang memengaruhi hasil belajar diantaranya motivasi belajar dan minat belajar. Rumusan masalah penelitian ini adalah bagaimana pengaruh motivasi belajar dan minat belajar terhadap hasil belajar peserta didik serta tujuan penelitian ini adalah mengetahui pengaruh motivasi belajar dan minat belajar terhadap hasil belajar peserta didik kelas VII MTs Al-Muttaqin Buper Jayapura. Penelitian ini merupakan penelitian kuantitatif dengan analisis data regresi linier berganda. Populasi dalam penelitian ini adalah seluruh peserta didik MTs Al-Muttaqin Buper Jayapura yang berjumlah 82 peserta didik. Sampel dalam penelitian ini adalah peserta didik kelas VII yang berjumlah 42 peserta didik. Teknik pengumpulan data yang digunakan adalah lembar angket motivasi dan minat serta tes hasil belajar peserta didik yang telah divalidasi oleh validator. Hasil penelitian menunjukkan bahwa: (1) ada pengaruh yang signifikan antara motivasi belajar terhadap hasil belajar dengan hasil penelitian diperoleh $t_{\text {hitung }} 4,042>t_{\text {tabel }} 2,02$; (2) ada pengaruh yang signifikan antara minat belajar terhadap hasil belajar dengan hasil penelitian diperoleh $t_{\text {hitung }} 4,315>$ $t_{\text {tabel }} 2,02$; (3) ada pengaruh yang signifikan antara motivasi dan minat belajar terhadap hasil belajar dengan hasil penelitian diperoleh $F_{\text {hitung }} 4,618>F_{\text {tabel }} 3,23$. Besar sumbangan motivasi dan minat belajar terhadap hasil belajar peserta didik sebesar $31,9 \%$.
\end{abstract}

Kata Kunci : Motivasi Belajar, minat belajar, hasil belajar

\section{PENDAHULUAN}

Pendidikan bukanlah sesuatu yang asing bagi setiap manusia di dunia ini. (Muhammad Anwar, 2015:20) mengatakan pendidikan diartikan sebagai hasil peradaban bangsa yang dikembangkan atas dasar pandangan hidup bangsa itu sendiri (nilai dan norma masyarakat), yang berfungsi sebagai filsafat pendidikannya atau sebagai cita-cita dan pernyataan tujuan pendidikannya. Jika hal tersebut dapat diwujudkan, maka nantinya manusia dapat menunjukkan cara berpikir dan berperilaku secara turun temurun, hingga kepada generasi berikutnya. Secara umum, tujuan pendidikan yaitu untuk mengembangkan potensi peserta didik agar menjadi manusia yang beriman dan bertakwa kepada Tuhan Yang Maha Esa, berakhlak mulia, sehat berilmu, cakap, kreatif, mandiri dan menjadi warga negara yang demokratis serta bertanggung jawab. Pendidikan perlu melakukan usaha yang sengaja dan terencana 
yang dilaksanakan pada semua jenis pendidikan yang ada, misal pendidikan di sekolah yang umumnya sering disebut sebagai pendidikan formal.

Berdasarkan Peraturan Menteri Pendidikan Nasional Republik Indonesia (Permendiknas) Nomor 23 Tahun 2006 Tentang Standar Kompetensi Lulusan Pasal 1 menyebutkan bahwa standar kompetensi lulusan untuk satuan pendidikan dasar dan menengah digunakan sebagai pedoman penilaian dalam menentukan kelulusan peserta didik. Standar kompetensi lulusan sebagaimana dimaksud meliputi standar kompetensi lulusan minimal satuan pendidikan dasar dan menengah, standar kompetensi lulusan minimal kelompok mata pelajaran, dan standar kompetensi lulusan minimal mata pelajaran. Menurut (Ratna Wilis Dahar, 2011:2) belajar dapat didefinisikan sebagai suatu proses dimana suatu organisasi berubah perilakunya sebagai akibat pengalaman. Melalui belajar, manusia mengaktualisasikan diri dan lingkungannya sehingga kualitas hidup dan kehidupan menjadi lebih baik. Belajar dapat dilakukan dimana saja, kapan saja dan oleh siapa saja yang mau melakukannya. Dalam situasi formal, belajar tidak dapat dipisahkan dari pembelajaran.

Menurut (Abdul Majid, 2014:122) mengatakan melalui belajar, manusia mengaktualisasikan diri dan lingkungannya sehingga kualitas hidup dan kehidupan menjadi lebih baik. Belajar dapat dilakukan dimana saja, kapan saja dan oleh siapa saja yang mau melakukannya. Dalam situasi formal, belajar tidak dapat dipisahkan dari pembelajaran. Peran guru dalam menyampaikan materi, sangat membantu peserta didik untuk memahami materi matematika yang diajarkan, meskipun pembelajaran matematika di kelas tidak selalu mulus sesuai keinginan guru. Masalah akan selalu ada dalam setiap pembelajaran di kelas. Menurut (Dimyati \& Mudjiono, 2013:235) Masalah dalam pembelajaran matematika di kelas yaitu: masalah dari segi sarana pembelajaran, masalah dari segi guru dan masalah dari segi peserta didik.

Berdasarkan hasil observasi di MTs Al-Muttaqin Buper Jayapura dimana sekolah ini merupakan sekolah yang berbasis agama, maka tidak dapat dipungkiri bahwa sekolah yang berbasis agama lebih mementingkan mata pelajaran agama dibandingkan mata pelajaran umum lainnya. Sehingga ditemukan beberapa permasalahan dalam kegiatan pembelajaran. Pertama, motivasi belajar peserta didik masih rendah ketika kegiatan pembelajaran berlangsung. Kondisi ini dibuktikan dengan banyaknya peserta didik yang melakukan aktivitas lain seperti berbicara, bermain dan tidur. Kedua, prestasi belajar sebagian besar peserta didik juga masih rendah berdasarkan hasil nilai ulangan harian sebanyak 55\% belum mencapai kriteria ketuntasan minimal.

Motivasi belajar adalah daya penggerak dalam diri peserta didik yang menimbulkan kegiatan belajar, yang menjamin kelangsungan dari kegiatan belajar dan memberikan arah pada kegiatan belajar, sehingga tujuan yang dikehendaki oleh subjek belajar itu dapat tercapai. Minat belajar adalah kecenderungan yang menetap dalam subjek untuk merasa tertarik pada bidang tertentu dan merasa senang berkecimpung dalam bidang itu. Hasil belajar matematika adalah merupakan tolak ukur atau patokan yang menentukan tingkat keberhasilan pesera didik dalam mengetahui dan memahami suatu materi pelajaran matematika setelah mengalami pengalaman belajar yang dapat diukur melalui tes.

Tujuan dari penelitian ini untuk mengetahui pengaruh motivasi belajar terhadap hasil belajar, pengaruh minat belajar terhadap hasil belajar, serta pengaruh motivasi dan minat belajar terhadap hasil belajar peserta didik kelas VII di MTs Al-Muttaqin Buper. 


\section{METODE}

Jenis penelitian yang dilakukan adalah jenis penelitian korelasi dengan pendekatan kuantitatif. Jenis penelitian korelasi adalah penelitian yang dilakukan peneliti untuk mengetahui tingkat pengaruh antar dua variabel atau lebih yang berkaitan dengan keadaan dan kejadian sekarang tanpa manipulasi data yang sudah ada.

Penelitian dilakukan di MTs Al-Muttaqin Buper Jayapura yang beralamat di Jalan Merah-Putih Buper Waena Heram Kota Jayapura. Penelitian dilakukan di kelas VII pada semester genap tahun ajaran 2019/2020.

Populasi yang peneliti gunakan yaitu seluruh peserta didik MTs Al-Muttaqin Buper Jayapura yang berjumlah 82 peserta didik. Sampel yang peneliti gunakan yaitu peserta didik kelas VII MTs Al-Muttaqin Buper Jayapura yang berjumlah 42 peserta didik.

Sumber data dalam penelitian ini yaitu data primer, dimana data yang diperoleh peneliti secara langsung melalui kuesioner dan tes hasil belajar. Variabel bebas dalam penelitian ini yaitu motivasi belajar peserta didik yang disimbolkan dengan $\left(X_{1}\right)$, dan minat belajar peserta didik yang disimbolkan dengan $\left(X_{2}\right)$. Dalam penelitian ini variabel terikatnya yaitu hasil belajar matematika pada peserta didik kelas VII MTs Al-Muttaqin Buper Jayapura, yang disimbolkan dengan $(Y)$.

Untuk memeroleh data yang relevan, maka metode pengumpulan data yang digunakan dalam penelitian ini yaitu kuesioner, tes hasil belajar dan dokumentasi. Instrumen yang digunakan dalam penelitian ini yaitu lembar kuesioner dan tes hasil belajar yang telah divalidasi oleh dosen ahli dan guru mata pelajaran matematika.

Uji prasyarat yang digunakan dalam penelitian ini adalah uji statistik non-parametrik Kolmogorov-Smirnov pada alpha 5\% dengan melihat data residunya apakah berdistribusi normal atau tidak. Dalam penelitian ini terdapat dua variabel bebas dan satu variabel terikat, sehingga koefisien korelasi yang dicari terdiri dari koefisien korelasi parsial dan koefisien korelasi ganda. Analisis yang peneliti gunakan yaitu analisis regresi linier berganda adalah hubungan secara linier antara dua atau lebih variabel independen dengan variabel dependen.

\section{HASIL}

Model data yang baik adalah memiliki distribusi normal atau mendekati normal. Data dikatakan normal jika Sign. atau probabilitas $>0.05$. Berikut adalah hasil normalitas data dengan uji kolmogorov-smirnov yang dihitung dengan menggunakan SPSS dari hasil perhitungan tersebut, diperoleh output sebagai berikut: 
Tabel 1. Hasil Uji Normalitas Data

One-Sample Kolmogorov-Smirnov Test

\begin{tabular}{|c|c|c|c|c|}
\hline & & $\begin{array}{c}\text { Motivasi } \\
\text { belajar }\end{array}$ & Minat Belajar & $\begin{array}{c}\text { Hasil } \\
\text { Belajar }\end{array}$ \\
\hline $\mathrm{N}$ & & 42 & 42 & 42 \\
\hline \multirow[t]{2}{*}{ Normal Parameters ${ }^{\mathrm{a}}$} & Mean & 81.93 & 84.45 & 91.07 \\
\hline & Std. Deviation & 9.288 & 3.542 & 1.644 \\
\hline Most Extreme Differences & Absolute & .113 & .122 & .233 \\
\hline & Positive & .113 & .122 & .136 \\
\hline & Negative & -.098 & -.104 & -.233 \\
\hline Kolmogorov-Smirnov Z & & .732 & .792 & 1.513 \\
\hline Asymp. Sig. (2-tailed) & & .658 & .557 & .785 \\
\hline
\end{tabular}

Test distribution is Normal.

Berdasarkan tabel 4.3 perhitungan dengan menggunakan SPSS, diperoleh nilai Asymp.Sig. $(2-$ tailed $)=0,658$ pada variabel bebas motivasi belajar $(X 1)$, Asymp.Sig. $(2-$ tailed $)=0,557$ pada variabel bebas minat belajar $(X 2)$, dan Asymp.Sig. $(2-$ tailed $)=0,785$ pada variabel terikat hasil belajar $(Y)$. Hal ini menunjukan bahwa hasil perhitungan atau Sign $>0,05$ sehingga data tersebut berdistribusi normal. Dapat disimpulkan bahwa data dalam penelitian memiliki varian yang sama dan data layak digunakan, sehingga data tersebut dapat dilanjutkan ke uji hipotesis.

Berdasarkan uji normalitas tersebut, maka data dapat dikatakan linier atau normal, sehingga analisis data product moment dapat digunakan dalam penelitian ini. Untuk uji korelasi product moment ini menggunakan SPSS. Berikut adalah hasil uji korelasi product moment yang dilakukan menggunakan SPSS untuk nilai dari $r_{Y 1}, r_{Y 2}$ dan $r_{12}$. 
Tabel 2. Hasil Uji Korelasi Product Moment

\section{Correlations}

\begin{tabular}{|ll|r|r|r|}
\hline & & $\begin{array}{c}\text { Motivasi Belajar } \\
\text { Matematika }\end{array}$ & $\begin{array}{c}\text { Minat Belajar } \\
\text { Matematika }\end{array}$ & $\begin{array}{c}\text { Hasil Belajar } \\
\text { Matematika }\end{array}$ \\
\hline Motivasi Belajar & Pearson & 1 & .070 & .168 \\
& Correlation & Sig. (2-tailed) & .660 & .287 \\
& $\mathrm{~N}$ & 42 & 42 & 42 \\
\hline Minat Belajar & Pearson & .070 & 1 & .061 \\
Matematika & Correlation & .660 & & .700 \\
& Sig. (2-tailed) & 42 & 42 & 42 \\
\hline N & Pearson & .168 & .061 & 1 \\
Masil Belajar & Correlation & .287 & .700 & 42 \\
\hline & Sig. (2-tailed) & 42 & 42 & \\
& $\mathrm{~N}$ & & & \\
\hline
\end{tabular}

Berdasarkan hasil perhitungan yang telah dilakukan diperoleh nilai koefisien korelasi $r_{12}$ yaitu korelasi antara motivasi belajar $(X 1)$ dengan minat belajar $(X 2)$ nilai pearson correlation Sig. 2-tailed $0,070>0,05$ yang berarti terdapat korelasi yang sangat rendah. Nilai koefisien korelasi $r_{Y 1}$ yaitu korelasi antara motivasi belajar $(X 1)$ dengan hasil belajar $(Y)$ nilai pearson correlation Sig. 2-tailed 0,168>0,05 yang berarti terdapat korelasi yang sangat rendah. Terakhir, nilai koefisien korelasi $r_{Y 2}$ yaitu korelasi antara minat belajar $(X 2)$ dengan hasil belajar $(Y)$ nilai pearson correlation Sig. 2tailed 0,61 >0,05 yang berarti terdapat korelasi yang tinggi. Berikut hasil uji regresi linier berganda yang dilakukan menggunakan SPSS:

Tabel 3. Hasil Uji Regresi Linier Berganda Model Summary ${ }^{b}$

\begin{tabular}{|c|c|c|c|c|c|c|c|c|c|c|}
\hline \multirow[b]{2}{*}{ Model } & \multirow[b]{2}{*}{$\mathrm{R}$} & \multirow[b]{2}{*}{\begin{tabular}{c|}
$\mathrm{R}$ \\
Square
\end{tabular}} & \multirow[b]{2}{*}{$\begin{array}{l}\text { Adjusted } \\
\text { R Square }\end{array}$} & \multirow[b]{2}{*}{$\begin{array}{l}\text { Std. Error } \\
\text { of the } \\
\text { Estimate }\end{array}$} & \multicolumn{5}{|c|}{ Change Statistics } & \multirow[b]{2}{*}{$\begin{array}{l}\text { Durbin- } \\
\text { Watson }\end{array}$} \\
\hline & & & & & $\begin{array}{c}\text { R } \\
\text { Square } \\
\text { Change }\end{array}$ & $\begin{array}{c}\mathrm{F} \\
\text { Change }\end{array}$ & & df2 & $\begin{array}{c}\text { Sig. F } \\
\text { Change }\end{array}$ & \\
\hline 1 & $.565^{\mathrm{a}}$ & .319 & -.019 & 1.659 & .319 & 4.618 & 2 & 39 & .005 & 2.293 \\
\hline
\end{tabular}

a. Predictors: (Constant), Minat Belajar Matematika,

Motivasi Belajar Matematika

b. Dependent Variable: Hasil Belajar

Matematika 
ANOVA $^{b}$

\begin{tabular}{|l|r|r|r|c|c|}
\hline Model & Sum of Squares & df & Mean Square & F & Sig. \\
\hline 1 Regression & 3.404 & 2 & 1.702 & 4.618 & $.005^{\mathrm{a}}$ \\
Residual & 107.382 & 39 & 2.753 & & \\
Total & 110.786 & 41 & & & \\
\hline
\end{tabular}

a. Predictors: (Constant), Minat Belajar Matematika, Motivasi Belajar Matematika

b. Dependent Variable: Hasil Belajar Matematika

\section{Coefficients $^{\mathrm{a}}$}

\begin{tabular}{|c|c|c|c|c|c|}
\hline \multirow[b]{2}{*}{ Model } & \multicolumn{2}{|c|}{$\begin{array}{c}\text { Unstandardized } \\
\text { Coefficients } \\
\end{array}$} & \multirow{2}{*}{$\begin{array}{c}\begin{array}{c}\text { Standardized } \\
\text { Coefficients }\end{array} \\
\text { Beta }\end{array}$} & \multirow[b]{2}{*}{$\mathrm{t}$} & \multirow[b]{2}{*}{ Sig. } \\
\hline & B & Std. Error & & & \\
\hline 1 (Constant) & 86.732 & 6.457 & & 13.432 & .000 \\
\hline $\begin{array}{l}\text { Motivasi Belajar } \\
\text { Matematika }\end{array}$ & .290 & .028 & .165 & 4.042 & .003 \\
\hline $\begin{array}{l}\text { Minat Belajar } \\
\text { Matematika }\end{array}$ & .230 & .073 & .050 & 4.315 & .007 \\
\hline
\end{tabular}

Dependent Variable: Hasil Belajar Matematika

Berdasarkan perhitungan manual dan perhitungan menggunakan bantuan SPSS didapat output nilai $R^{2}=0,319$, nilai variabel konstanta atau $\alpha$ sebesar 86,732, nilai variabel $(X 1)$ atau $\alpha_{1}$ sebesar 0,290 , nilai variabel $(X 2)$ atau $\alpha_{2}$ sebesar $=0,230$, nilai $t_{\text {hitung }}$ $(X 1)=4,042$, nilai $t_{\text {hitung }}(X 2)=4,315$, nilai $F_{\text {hitung }}=4,618$, nilai Sign 0,005.

\section{PEMBAHASAN}

Berdasarkan perhitungan yang telah diuraikan, diketahui bahwa nilai koefisien regresi variabel motivasi belajar $(X 1)$ adalah sebesar 0,290, sehingga dapat dikatakan bahwa motivasi belajar $(X 1)$ berpengaruh terhadap hasil belajar $(Y)$. Selanjutnya, untuk mengetahui apakah pengaruh tersebut signifikan atau tidak, maka nilai koefisien regresi dari variabel motivasi belajar $(X 1)$ ini akan diuji signifikansinya.

Berdasarkan hasil analisis regresi diperoleh nilai $t_{\text {hitung }}$ sebesar 4,042 $>t_{\text {tabel }} 2,02$. Maka dapat disimpulkan bahwa $H_{0_{M o}}$ ditolak dan $H_{a_{M o}}$ diterima, yang artinya motivasi belajar $(X 1)$ berpengaruh signifikan terhadap hasil belajar $(Y)$. Berdasarkan hasil analisis regresi diperoleh nilai $t_{\text {hitung }}$ sebesar $4,315>t_{\text {tabel }} 2,02$. Maka dapat disimpulkan bahwa $H_{0_{M i}}$ ditolak dan $H_{a_{M i}}$ diterima, yang artinya minat belajar $(X 1)$ berpengaruh signifikan terhadap hasil belajar $(Y)$. Maka diketahui nilai $F_{\text {tabel }}$ sebesar 3,23 karena nilai $F_{\text {hitung }} 4,618>F_{\text {tabel }}$ 3,23 maka dapat ditarik kesimpulan bahwa variabel bebas $(X 1)$ dan $(X 2)$ (secara simultan) berpengaruh terhadap variabel terikat $(Y)$.

Analisis data dengan menggunakan SPSS, menunjukkan ada pengaruh yang signifikan antara motivasi belajar terhadap hasil belajar matematika berdasarkan $t_{\text {hitung }} 4,042>$ 
$t_{\text {tabel }} 2,02$ pada taraf Sign $0.003<0,05$ (taraf 5\%) seperti pada tabel output Uji TParsial. Karena nilai $0.003<0.05$, maka hipotesis kerja diterima yang artinya ada pengaruh yang berarti antara motivasi belajar terhadap hasil belajar matematika peserta didik kelas VII MTs Al-Muttaqin Buper Jayapura. Nilai koefisien $R$ Square sebesar $31,9 \%$ yang bertandakan positif memiliki arti bahwa semakin tinggi motivasi belajar peserta didik, maka semakin tinggi pula hasil belajar peserta didik yang dicapainya atau semakin rendah motivasi belajar yang dia miliki maka semakin rendah pula hasil belajarnya.

Analisis data dengan menggunakan SPSS yang menunjukkan ada pengaruh yang signifikan antara minat belajar terhadap hasil belajar matematika berdasarkan nilai $t_{\text {hitung }} 4,315>t_{\text {tabel }} 2,02$ pada taraf Sign 0,007 $<0.05$ (taraf 5\%) seperti pada tabel output Uji T-Parsial. Karena nilai $0.007<0.05$, maka hipotesis diterima yang artinya ada pengaruh yang berarti antara minat belajar terhadap hasil belajar matematika peserta didik kelas VII MTs Al-Muttaqin Buper Jayapura.

Analisis data dengan menggunakan SPSS yang menunjukkan ada pengaruh yang signifikan antara motivasi dan minat belajar terhadap hasil belajar matematika berdasarkan Signifikansi Uji-F sebesar 0,005 $<0,05$ atau $F_{\text {hitung }} 4,618>F_{\text {tabel }} 3,23$ pada taraf Sign 0.05 (taraf 5\%) seperti pada tabel output Uji F-Simultan. Karena $0,005<0,05$, maka hipotesis kerja diterima yang artinya ada pengaruh yang berarti antara motivasi dan minat belajar terhadap hasil belajar matematika peserta didik kelas VII MTs Al-Muttaqin Buper Jayapura.

\section{KESIMPULAN}

Berdasarkan hasil perhitungan yang diperoleh, yaitu $t_{\text {hitung }} 4,042>t_{\text {tabel }} 2,02$ menunjukkan bahwa motivasi belajar memberikan pengaruh yang signifikan terhadap hasil belajar peserta didik kelas VII di MTs Al-Muttaqin Buper Jayapura. Kemudian hasil perhitungan yang diperoleh, yaitu $t_{\text {hitung }} 4,315>t_{\text {tabel }} 2,02$ menunjukkan bahwa minat belajar memberikan pengaruh yang signifikan terhadap hasil belajar peserta didik kelas VII di MTs Al-Muttaqin Buper Jayapura. Sedangkan hasil

perhitungan yang diperoleh, yaitu $F_{\text {hitung }} 4,618>F_{\text {tabel }} 3,23$ menunjukkan bahwa motivasu belajar dan minat belajar secara simultan memberikan pengaruh terhadap hasil belajar peserta didik kelas VII di MTs Al-Muttaqin Buper Jayapura. Nilai pengaruh motivasi belajar dan minat belajar yaitu sebesar 31,9\%.

Penelitian ini dilakukan pada saat pandemi covid-19, sehingga penelitian ini menjadi kurang maksimal. Faktor-faktor yang mempengaruhi hasil belajar peserta didik dalam penelitian ini hanya terdiri dari motivasi dan hasil belajar, sedangkan masih banyak faktor lain yang mempengaruhi hasil belajar peserta didik. Adanya keterbatasan penelitian dengan menggunakan kuesioner yaitu terkadang jawaban yang diberikan oleh sampel tidak menunjukkan keadaan sesungguhnya.

\section{DAFTAR PUSTAKA}

\section{Buku:}

Anwar, Muhammad. (2015). Filsafat Pendidikan. Jakarta: Prenadamedia Group.

Amir, Zubaidah dan Risnawati. (2015). Psikologi Pembelajaran Matematika. Yogyakarta: Aswaja Pressindo. 
Awwalina, Lia Nur. (2015). Pengaruh Mind Mapping dan Motivasi Terhadap Hasil Belajar Matematika Siswa Kelas VIII MTs Ma'arif Karangan. Skripsi. Tulungagung: Institut Agama Islam Negeri Tulungagung.

Dimyati \& Mudjiono. (2013). Belajar \& Pembelajaran. Jakarta: PT. Rineka Cipta.

Hamalik, Oemar. (2013). Proses Belajar Mengajar. Jakarta: PT. Bumi Aksara.

Majid, Abdul. (2014). Belajar Dan Pembelajaran: Pendidikan Agama Islam. Bandung: PT. Remaja Rosdakarya.

Siregar, Syofian. (2017). Statistik Parametrik untuk Penelitian Kuantitatif. Jakarta: PT Bumi Aksara.

Larasati, Irenne. (2016). Pengaruh Motivasi Belajar Dan Minat Belajar Terhadap Hasil Belajar Matematika Materi Persamaan Linear Satu Variabel Pada Siswa Kelas VII-C SMP BOPKRI 1 Yogyakarta. Skripsi. Yogyakarta: Universitas Sanata Dharma.

Nurjanah, Siti. (2016). Hubungan Motivasi Guru Dengan Hasil Belajar Matematika Siswa Di SMP Negeri 177 Jakarta. Skripsi. Jakarta: Universitas Islam Negeri Syarif Hidayatullah.

Setiawan, Agus. (2015). Hubungan Antara Motivasi Belajar dan Minat Baca dengan Prestasi Belajar Siswa Kelas VIII SMPN2 Sumbergempol. Skripsi. Tulungagung: Institut Agama Islam Negeri Tulungagung,.

Suryani, Ade Irma. (2015). Pengaruh Minat Dan Cara Belajar Terhadap Hasil Belajar Matematika Pada Siswa Kelas VIII SMP Inshafuddin Banda Aceh. Skripsi. Banda Aceh: Universitas Syiah Kuala Darussalam. 